\title{
Prevalence of PTSD in the Kerman schools students witnessing the Bam earthquake scenes on TV
}

\author{
Farshid Khosropour ${ }^{1 *}$, Marjan Farahmand ${ }^{2}$, Rostam Yazdani ${ }^{3}$ \\ From $1^{\text {st }}$ International Congress on Neurobiology and Clinical Psychopharmacology and European \\ Psychiatric Association Conference on Treatment Guidance \\ Thessaloniki, Greece. 19-22 November 2009
}

\section{Background}

Observing horrible scenes may lead to PTSD, also it is possible that observing these scenes on TV may lead to PTSD, however it is controversial.

\section{Materials and methods}

Using a cluster sampling procedure, 300 students from the Kerman schools were selected. A PTSD symptoms check list along with the DSM-IV diagnostic criteria were used to detect the symptoms 3 months after the Bam quake. All of them witnessed the Bam earthquake scenes on TV for at least one hour.

\section{Results}

Result indicated that 195 were without any symptoms, 40 had the re-experience of the events in the form of repetitive remembering, 20 had avoidant behaviors, 19 had showed irritability, and 16 had detachment, and 10 had the full picture of the PTSD.

\section{Conclusions}

Considering the prevalence of the PTSD across children, care should be taken regarding observation of the horrible scenes by children.

\section{Author details}

${ }^{1}$ Psychology Department, Islamic Azad University, Zarand Branch, Kerman, Iran. ${ }^{2}$ High Technology, Roshd Center, Kerman, Iran. ${ }^{3}$ Medical Sciece University, Kerman, Iran.

Published: 22 April 2010

${ }^{1}$ Psychology Department, Islamic Azad University, Zarand Branch, Kerman, Iran

\section{References}

1. Aulagnier $M$, Verger $P$, Rouillon F: Efficacy of psychological debriefing in oreventing PTSD. Rev Epidemiol Sante Publique 2004, 52(1):67-79.

2. Bland SH, Valoroso L, Stranges S: long-term follow-up of psychological distress following earthquake experiences among working Italian males. J Nerv Ment Dis 2005, 193(6):420-423.

3. Taylor M, Jenkins K: The psychological impact of September 11 terroism on Australian inpatients. Australas psychiatry 2004, 12(3):253-265.

4. Cao H, Mcfarlane AC, Klimidus S: Prevalence of psychiatric disorder following the 1988 Yun Nan (China) earthquake - the first 5-month period. Soc psychiatry Epidemiolo 2003, 38(4):204-212.

doi:10.1186/1744-859X-9-S1-S84

Cite this article as: Khosropour et al:: Prevalence of PTSD in the Kerman schools students witnessing the Bam earthquake scenes on TV. Annals of General Psychiatry 2010 9(Suppl 1):S84.
Submit your next manuscript to BioMed Central and take full advantage of:

- Convenient online submission

- Thorough peer review

- No space constraints or color figure charges

- Immediate publication on acceptance

- Inclusion in PubMed, CAS, Scopus and Google Scholar

- Research which is freely available for redistribution

Submit your manuscript at www.biomedcentral.com/submit
C Biomed Central 